\title{
Społeczny, ekonomiczny i kulturowy wymiar widowiska sportowego
}

\section{Abstract \\ Social, Economic and cultural dimension of sporting spectacle}

Sports event is this aspect of sport, which is experienced by most people. Sports games, competitions, matches shape the image of the sport in the popular consciousness

The article includes analysis of the sporting spectacle - the essential aspects and function. The analysis aimed to identify possible prospects of viewing sport as a social phenomenon. As a result of the analysis, nine possible prospects were identified as possible discussion on the sports spectacle. Sports competitions, matches can be viewed from the following perspectives symbolic, emotional, recreation and health, economic, social and political, architectural as well as in the perspective of art and media.

\section{Wprowadzenie}

Sport jest zjawiskiem wielowymiarowym. Pozostaje w relacji do niemal wszystkich ważniejszych dziedzin życia społecznego. Bez większego trudu można wskazać na jego powiązania z podstawowymi dziedzinami życia, takimi jak gospodarka, edukacja, kultura i sztuka oraz polityka. Sport odnosi się zarówno do obszaru nauk przyrodniczych, jak i społecznych, wiedzy o samym człowieku, jak i wiedzy o społeczeństwie, tak anatomii, fizjologii czy psychologii, jak i ekonomii oraz socjologii. Jest zjawiskiem społecznym o zasięgu ogólnoświatowym i skali wypełniającej życie współczesnego człowieka w zakresie daleko wykraczającym 
poza jego realne zainteresowania sportem i realny w nim udział. Bez względu na to, jak duży jest ten udział - deklarowane i rzeczywiste funkcjonowanie w obszarze sportu - dotyka on każdego bez wyjątku. Do tego pozostaje on prawdopodobnie w większym stopniu poza uświadomionym obszarem rzeczywistości niż w jego części uświadomionej.

Dziś trudno sobie wyobrazić (jest to wręcz niemożliwe) życie społeczne bez tego, co określa się mianem sportu. Zjawisko, które przenika życie społeczne i jednostkowe w tak dużym stopniu, sytuuje się w sferze istotnych potrzeb tak w wymiarze zbiorowym, jak i indywidualnym . Fakt ten sam w sobie jest wielce zastanawiający i godny osobnych rozważań, szczególnie jeśli się uwzględni, że zjawisko sportu, w kształcie, jaki dziś obserwujemy, liczy sobie zaledwie ok. 150 lat.

To, bez czego nie jesteśmy w stanie wyobrazić sobie dzisiaj życia, mogło zupełnie nie istnieć realnie, jak i w sferze mentalnej, w sferze potrzeb i zainteresowań, przez setki i tysiące lat historii gatunku ludzkiego. Innymi słowy, nie interesowało człowieka, nie odczuwał, a nawet nie zauważał on jego braku aż do niemal początku XX wieku. Starożytne igrzyska olimpijskie i średniowieczne turnieje rycerskie jako pierwowzory sportowej rywalizacji w dzisiejszym wydaniu są zjawiskami odmiennymi w stosunku do złożonego zjawiska współczesnego sportu. Podobne w pewnych aspektach - istoty, warunków czy form rywalizacji - różnią się one z uwagi choćby na złożoność i skalę zjawiska. Wprawdzie grecka kultura antyczna nie może obyć się bez antycznej agonistyki, z najbardziej rozwiniętymi co do formy, o najdłuższej i najlepiej poznanej historii (1169 lat), igrzyskami olimpijskimi, to jednak należy pamiętać, że były to specyficzne formy obrzędowości religijnej starożytnych o stosunkowo zawężonym - do kilku form rywalizacji z obszaru współczesnej lekkiej atletyki, zapasów i wyścigów - zakresie. Także i kwestia wyłaniania zwycięzców (wygrywał bez względu na rezultaty w innych konkurencjach tryumfator w zapasach) różni zdecydowanie rywalizację antycznych zawodników od współczesnych sportowców. Wspólne są pewne elementy rywalizacji, jak na przykład poszanowanie zasad rywalizacji, ze średniowiecznym fair play wywodzącym się z etosu rycerskiego, zakładającego równość szans walczących stron, na czele.

Wspólny jest też element widowiskowości. Zawody antyczne czy średniowieczne turnieje uwzględniały kwestie widowiskowości rywalizacji w jeszcze większym stopniu niż współcześnie. To oglądanie zmagań zawodników stanowiło istotę całego zjawiska, a widz, obserwator i jego czynność śledzenia tych wydarzeń sytuowały się niejako w jego centrum. Wszelkie zmagania antycznych olimpioników i średniowiecznych rycerzy - były dla widzów, dla ich przyjemności, rozrywki, jako źródło wrażeń i emocji. Co ciekawe, współczesny sport, mimo iż stale ewoluuje, nie uwzględnia widza w takim stopniu i zakresie jak zmagania „sportowe” sprzed wieków. W niektórych przypadkach widz jest wręcz dodatkiem i to niezbyt istotnym. Wynika to z różnorodności form rywalizacji, także takich, gdzie areną zmagań jest przestrzeń mało dostępna dla obserwatora, a rywalizacja przebiega w stosunkowo wąskim gronie bezpośrednio zainteresowanych.

Podsumowując, sport jako obszar życia społecznego, istotna część kultury i pewien ryt współczesnej cywilizacji jest zjawiskiem nowym. W zestawieniu z jego skalą we współczesnej cywilizacji i dynamiką rozwoju można mówić o fenomenie 
sportu. Coś, co nie istniało i zdawało się niepotrzebne przez setki i tysiące lat, pojawia się i natychmiast niejako staje się jedną z podstawowych potrzeb człowieka i społeczeństw, staje się czymś, bez czego nie można sobie wyobrazić życia. Jedyna możliwa analogia do zjawiska sportu we współczesnym świecie, jaka się nasuwa, to analogia do zjawiska motoryzacji i jego rozwoju. Dotyczy ona zarówno czasokresu pojawienia się (druga połowa XIX w.), dynamiki rozwoju - od „zera” do jednej z najistotniejszych dziedzin życia w ciągu niewiele ponad 100 lat, jak i skali - jako jeden z najważniejszych obszarów funkcjonowania współczesnego człowieka.

\section{Rodowód sportu}

Samo pojęcie sportu pojawia się na przełomie wieków XIX i XX. Drukowany w latach 50. XIX wieku (od 1854 do 1860 roku) sześciotomowy słownik Samuela Bogumiła Lindego pojęcia sportu nie zawiera. Podobnie jak Encyklopedia staropolska Zygmunta Glogera z lat 1900-1903. Pojawia się ono w Słowniku języka polskiego Karłowicza z 1915 roku$^{1}$, i to w postaci nieprzystającej do jego dzisiejszego znaczenia, a nawet zaskakującej swoją formą. W tomie szóstym tego słownika czytamy, że sport to: „rozrywka wymagająca ruchu i zręczności, jak wyścigi konne, polowanie, wioślarstwo”. Dalej mowa jest o „oddawaniu się sportowi” i „uprawianiu sportu”, w obręb którego włączone są sporty: „łyżwowy, wioślarski, cyklistowski”, jak również o - jak można sądzić - pewnych „zachowaniach sportowych” (,robił sobie sport z rzucania kamykami w przechodniów”). Jest też pojęcie „sportman” (sportowiec) tłumaczone (z ang. sportsman) jako „wielki myśliwy, wielki koniarz”, a także pojęcie „sportować”, oznaczające zajmowanie się sportem, uprawianie sportu, oddawanie się sportowi (Słownik języka polskiego 1952, s. 319).

Jazda konna, a raczej przejażdżki konne czy myślistwo, to aktywności, jakim oddawały się wyższe warstwy społeczeństwa dla przyjemności i rozrywki. Podkreślały one jednocześnie ich status społeczny, w tym możliwości finansowe pozwalające na realizację takich zachowań. Dodatkowym elementem czy sposobem podkreślającym odrębność i elitarność stały się w drugiej połowie XIX wieku zachowania, które wówczas uchodziły za ekstrawaganckie, takie jak pływanie, wioślarstwo, różne gry z piłką czy osławiona cyklistyka, a więc jazda na genialnym, szybko upowszechniającym się wynalazku tamtych czasów - rowerze. Jest o nich mowa w cytowanej wyżej definicji. Wraz z tradycyjnymi zachowaniami

1 Pierwsze źródło w języku polskim analizujące pojęcie sportu to Słownik języka polskiego Karłowicza z 1915 roku, szerzej dostępne w wydaniu fotooffsetowym: Słownik języka polskiego, red. J. Karłowicz, A. Kryński, W. Niedźwiedzki, tom VI, Państwowy Instytut Wydawniczy, Warszawa 1952, s. 319. Z pierwodruku: Słownik języka polskiego Jana Karłowicza, Adama Kryńskiego, Władysława Niedźwiedzkiego, tom VI, S- Ś. Ułożony przez Władysława Niedźwiedzkiego z udziałem Kazimierza Króla. Dzieło nagrodzone przez krakowską akademię Umiejętności na konkursie imienia Lindego i zalecone przez Galicyjską Radę Szkolną do użytku szkół. Warszawa 1915, nakładem prenumeratorów i Kasy im. Mianowskiego. W drukarni „Gazety Handlowej” Szpitalna 10. 
arystokracji stanowiły one obszar zajęć nieproduktywnych, właściwych dla „klasy próżniaczej”, będących rodzajem ostentacyjnej konsumpcji. Do ich nazwania użyto słowa „sport” od łac. se desportare, oznaczającego zabawę, przyjemne spędzanie czasu, oddawanie się rozrywkom.

Sport zatem, przynajmniej w swej warstwie pojęciowej, ma pochodzenie arystokratyczne i dziewiętnastowieczne, co nie eliminuje innych źródeł różnorodnych form aktywności sportowej. Pojawią się one szybko, zwracając uwagę tkwiącymi w nich wartościami o charakterze społecznym, na które ujawni się niejako swoiste zapotrzebowanie.

Ciało ludzkie i jego ruch jest źródłem przyjemnych doznań, zadowolenia, komfortu, satysfakcji, rekreacji. Sport, posługując się ruchem jako podstawowym atrybutem (są tu wyjątki), staje się nośnikiem wartości, których źródłem jest właśnie ruch. Wartości przyjemnościowe (felicytologiczne - odnoszące się do szczęścia, wewnętrznego uczucia zadowolenia, możliwości urzeczywistniania przez człowieka jego pragnień), obok wartości witalnych i wartości duchowych stanowią własność sportu. Tłumaczy to jednocześnie, dlaczego sport jest domeną szczególnie ludzi młodych - z racji ich biologicznych, fizjologicznych, psychicznych i duchowych potrzeb.

Sport, a właściwie zachowania sportowe, mają także swoje uzasadnienie i rodowód historyczny. Najczęściej powtarzaną w tym miejscu tezą jest ta, że sport jest przetworzoną formą walki zbrojnej. Przetworzenie to polegało na nadaniu walce ścisłych reguł i wyeliminowaniu ofiar. Walka jako naturalna skłonność człowieka do agresji i dominacji, służąc jednocześnie zapewnieniu lub poprawie jego bytu, występuje w całej jego filogenezie, stanowiąc podstawową formę i rys charakterystyczny tej egzystencji. Sport zatem to nic innego jak tylko kontynuacja i źródło realizacji właściwych człowiekowi cech i skłonności we współczesnych, bardziej cywilizowanych warunkach.

Innym, rzadziej spotykanym uzasadnieniem historycznego rodowodu niektórych dziedzin sportu jest to, że są one obszarami rywalizacji w zakresie wybranych form umiejętności i zdolności roboczej człowieka, podejmowanymi w różnych, czasami odległych okresach jego dziejów. Weryfikacja doskonalonych umiejętności i sprawności wykorzystywanych w czynnościach codziennych, w formie wzajemnej rywalizacji o prymat (mistrzostwo), z pewnością miała miejsce w długiej historii cywilizacyjnego rozwoju człowieka. Te zaś można można odnaleźć chociażby w konkurencjach lekkoatletycznych.

\section{Definiowanie sportu}

Żeby uchwycić i poddaćanalizie nakreślony fenomen - polegający na zafunkcjonowaniu zjawiska sportu w tak wielkiej skali w sferze potrzeb społecznych i jednostki na przestrzeni jednego stulecia, z tysięcy, jakie liczy gatunek ludzki - należy odwołać się do precyzyjnego zdefiniowania tej kategorii pojęciowej. Przegląd słownikowych definicji sportu, jak i definicji zawartych w innych źródłach (np. aktach prawnych) wskazuje na ich znaczne zróżnicowanie. 
W Wielkiej encyklopedii powszechnej PWN z 1967 roku (t. 10, s. 719) czytamy, że sport to „działalność mająca na celu podnoszenie sprawności fizycznej i jej manifestację, uprawiana systematycznie wg pewnych reguł, w której występuje pierwiastek współzawodnictwa i dążenie do osiągania jak najlepszych wyników". Nieco inaczej termin ten zdefiniowany został w Wielkiej encyklopedii PWN z roku 2004 (t. 25, s. 454) - sport to „z założenia pokojowe współzawodnictwo, którego istotę stanowi indywidualna lub zespołowa rywalizacja (wg określonych reguł) prowadzona zgodnie z zasadami fair play, oraz dążenie do coraz lepszych wyników, podejmowane także m.in. w celu rekreacji i doskonalenia własnych cech fizycznych". W obydwu opracowaniach zawarte jest ważne zastrzeżenie mówiące, że „wobec wieloznaczności pojęcia «sport» jest to tylko jedna z wielu możliwych definicji". Zastrzeżenie to samo w sobie ujmuje istotę rzeczy w definiowaniu sportu jako kategorii pojęciowej i zjawiska kulturowego i społecznego, jak i czynności w obszarze biologiczno-fizjologicznym czy anatomiczno-motorycznym. Mówiąc bowiem o możliwości różnorodnych podejść do problemu jako trudności czy barierze w definiowaniu sportu, w istocie najlepiej definiuje sport jako kategorię pojęciową „niedefiniowalną”. Krzysztof Zuchora ujął to w tytule swojej książki z 1976 roku - Sport niejedno ma imię.

Aspekt biologiczno-fizjologiczny zjawiska sportu akcentowany jest w definicjach słownikowych, z natury bardziej lakonicznych - a więc zorientowanych na uchwycenie najistotniejszego elementu danej kategorii. Tu sport definiowany jest jako „różne ćwiczenia fizyczne i gry, które wymagają sprawności fizycznej i w których ludzie uczestniczą dla przyjemności lub aby współzawodniczyć z innymi" (Słownik języka polskiego PWN 2000, s. 655) lub „ćwiczenia i gry mające na celu rozwijanie sprawności fizycznej i dążenie we współzawodnictwie do uzyskania jak najlepszych wyników” (Słownik poprawnej polszczyzny 1973), lub „ćwiczenia i gry mające na celu podnoszenie sprawności fizycznej; próbowanie swoich sił w różnych dziedzinach wymagających sprawności fizycznej" (Mały słownik języka polskiego 1989, s. 768), lub „ćwiczenia i gry mające na celu podnoszenie sprawności fizycznej i jej demonstrowanie; sprzyjające zachowaniu i rozwijające cenne cechy osobowości (wytrwałość, silną wolę, zdyscyplinowanie itp.)" (Popularny słownik języka polskiego 2003, s. 555).

Pojęcie sportu definiowane na potrzeby różnych regulacji prawnych w kolejnych ustawach o kulturze fizycznej i sporcie przedstawia się z kolei następująco: w ustawie o kulturze fizycznej z 1984 roku „sport jest procesem polegającym na doskonaleniu sprawności psychofizycznej, zaspokajającym potrzeby rywalizacji i dążenia do osiągnięcia wyników w ramach społecznie akceptowanych zasad współzawodnictwa”2; w ustawie o kulturze fizycznej z 1996 „sport jest formą aktywności człowieka, mającą na celu doskonalenie jego sił psychofizycznych, indywidualnie lub zbiorowo według reguł umownych"3; w ustawie o sporcie z 2010 „sportem są wszelkie formy aktywności fizycznej, które przez uczestnictwo doraźne lub zorganizowane wpływają na wypracowanie lub poprawienie kondycji

2 Ustawa z dnia 3 lipca 1984 roku o kulturze fizycznej. Dz.U. z 1984 r. Nr 34, poz. 181, art. 1 ust. 2 pkt. 3

3 Ustawa z dnia 18 stycznia 1996 roku o kulturze fizycznej. Dz.U. z 1996 r. Nr 25, poz. 113, art. 3 pkt 3. 
fizycznej i psychicznej, rozwój stosunków społecznych lub osiągnięcie wyników sportowych na wszelkich poziomach"4.

W literaturze przedmiotu, źródłach merytorycznie powiązanych z kulturą fizyczną, definiowanie sportu z oczywistych względów ma charakter kompleksowy (by ująć wszystkie aspekty), jak i bardziej opisowy, co nie oznacza w dalszym ciągu, że ujednolicony. Tu także, a może i w większym stopniu, mamy do czynienia z różnorodnością podejść i koncepcji. I tak w encyklopedii sportu czytamy, że sport to: „świadoma, dobrowolna działalność człowieka, podejmowana głównie dla zaspokojenia potrzeby zabawy, popisu, walki, a także potrzeby wewnętrznego doskonalenia się $w$ drodze systematycznego rozwoju cech fizycznych, umysłowych i wolicjonalnych. Współzawodnictwo sportowe (indywidualne i zespołowe), którego specyficzną formą jest system zawodów, ma charakter nieantagonistyczny, a warunki, w jakich się toczy i przepisy, które go określają mają na celu obiektywne i precyzyjne porównanie walorów, zdolności i umiejętności ludzkich, zapewniając możliwość ich maksymalnego przejawiania się. Celem współzawodnictwa sportowego jest pokonanie czasu, przestrzeni, przeciwnika lub dążenie do osiągnięcia idealnej (umownie) postaci wzorca ruchowego" (Mała Encyklopedia Sportu 1984, s. 439).

W Humanistycznej Encyklopedii Sportu Wojciecha Lipońskiego sport zdefiniowany został jako „świadoma aktywność człowieka, której istotę stanowią:

1) indywidualne lub zespołowe współzawodnictwo ludzi (niekiedy z udziałem zwierząt) w pokonywaniu czasu, przestrzeni, przeszkód naturalnych lub sztucznych oraz przeciwnika, przy czym elementy te występują łącznie lub rozdzielnie w proporcjach zależnych od dyscypliny sportu;

2) doskonalenie walorów fizycznych jak siła, szybkość, skoczność, wytrzymałość, zręczność i precyzja działania, równolegle do doskonalenia sił psychicznych, w tym cech woli i charakteru, zasad moralnych i umiejętności taktyczno-koncepcyjnych;

3) dobrowolność uczestnictwa;

4) podporządkowanie się regułom gry - skodyfikowanym, uznawanym zwyczajowo lub doraźnie umownym, wynikającym z istoty danej dyscypliny lub konkurencji sportu, a pod względem etycznym z zasad fair play;

5) brak bezpośrednich celów pozasportowych, jak militarnych i produkcyjnych" (Humanistyczna Encyklopedia Sportu 1987, s. 312). W stosunku do najczęściej wymienianych elementów definiujących kategorię sportu eksponuje się tu „dobrowolność” uczestnictwa i brak celów (czytaj: korzyści) pozasportowych, wśród których wymienia się tylko militarne i produkcyjne, nie uwzględniając innych, takich jak na przykład ekonomiczne.

Różne definicje sportu zawierają najbardziej znane opracowania podręcznikowe z zakresu teorii wychowania fizycznego autorstwa Macieja Demela czy Henryka Grabowskiego. Odmienności wynikają z przyjętej koncepcji, rozłożenia akcentów (klasyfikacji istotności poszczególnych składowych definicji), jak i odmiennego postrzegania celu tego rodzaju aktywności człowieka (manifestacja sprawności ruchowej u Demela i zaspokojenie potrzeby samorealizacji u Grabowskiego).

4 Ustawa z dnia 25 czerwca 2010 roku o sporcie. Dz.U. z 2010 r. Nr 127, poz. 857, art. 2 ust. 1. 
Demel w swojej definicji wylicza poszczególne elementy składające się na kryteria kwalifikujące do kategorii sportu - „sport to działalność uprawiana systematycznie, według pewnych reguł, odznaczająca się silnym pierwiastkiem współzawodnictwa oraz tendencją do osiągania coraz lepszych wyników, mająca na celu manifestację sprawności ruchowej" (Demel, Skład 1974, s. 18; 1986, s. 16; 1995, s. 34). Grabowski z kolei, definiując sport, odnosi go do kategorii ogólniejszej (nadrzędnej) i stwierdza, że „sport to forma uczestnictwa w kulturze fizycznej ludzi o odpowiednich predyspozycjach somatyczno-perfekcjonistycznych, których celem jest zaspokojenie potrzeby samorealizacji na drodze współzawodnictwa w dążeniu do osiągnięcia maksymalnych rezultatów w zakresie sprawności fizycznej i ruchowej" (Grabowski, 1999, s. 45)5.

Dokonując zbiorczego zestawienia kryteriów kwalifikujących daną aktywność do miana sportu, definiujących sport, będących jego wyznacznikami, wymienić należy: współzawodnictwo (rywalizacja to charakterystyczny i na ogół bezwyjątkowy wyznacznik sportu); nastawienie na rozwój i stałe podnoszenie osiągów (tendencja, dążenie do osiągnięcia coraz lepszych maksymalnych rezultatów) w zakresie sprawności fizycznej i ruchowej; ukazanie, publiczny pokaz, popis, manifestacja sprawności fizycznej; systematyczność; reguły (działalność wykonywana według pewnych reguł); miejsce (widowisko sportowe, zawody, mecz); a także dążenie do wyróżnienia się i wykazania swojej przewagi nad innymi, gotowość do poświęcania innych wartości w imię powyższych.

W zależności zatem czy mówimy o sporcie jako doskonaleniu walorów fizycznych, kształtowaniu i wynoszeniu na wyżyny sprawności fizycznej (psychofizycznej), czy jako o procesie nauczania i kształtowania opartym o systematyczną pracę, czy jako o pewnej formie zachowań zabawowych i rekreacyjnych wynikających z potrzeb, czy jako o formie rywalizacji, współzawodnictwie jednostek i grup osób w różnorodnych czynnościach, czy jako o formach działań określanych ścisłymi regułami (dyscyplinach i konkurencjach sportowych), czy wreszcie mówimy o sporcie jako widowisku, przedstawieniu realizowanym i reżyserowanym (tu na najwyższym poziomie, bo bez rozwiązania, a więc reżyserii wszelkich możliwych zdarzeń) na potrzeby grupy społecznej (potrzeby społeczne, polityczne) - to każdorazowo odnosimy się do innej rzeczywistości. Za każdym razem wstępujemy na inny, choć powiązany z pozostałymi, teren rozważań i analiz, w inną dziedzinę wiedzy, nauki, inne kryteria klasyfikacji i systematyzacji, przyjmujemy inną perspektywę poznawczą.

5 Dla porównania definicja sportu tego autora z wcześniejszego opracowania (H. Grabowski, Teoria wychowania fizycznego, AWF, Kraków 1987, s. 34) brzmi nieco inaczej: „sport to forma uczestnictwa w kulturze fizycznej ludzi posiadających odpowiednie predyspozycje somatyczno-motoryczne, której celem jest zaspokajanie potrzeby samorealizacji na drodze współzawodnictwa w dążeniu do osiągania maksymalnych rezultatów w zakresie sprawności fizycznej i ruchowej”. 


\section{Perspektywy sportu}

Sport można rozpatrywać zarówno z perspektywy zabawy (zachowań ludycznych), jak i instytucji, środka wychowania, widowiska, zdrowia (sprawności fizycznej), etyki (zasad, wymogów etycznych). Sport to jednocześnie, biorąc pod uwagę zasięg - obszerna dziedzina życia społecznego, uwzględniając zaś jego wymiar ekonomiczny - swoista gałąź przemysłu i usług. Odnosząc się do jego zasadniczych wyznaczników, jakimi są rywalizacja i dążenie do stałego rozwoju własnych możliwości, możemy stwierdzić, że stanowi składową ontologii istoty ludzkiej, natomiast gdy patrzymy na sport w jego najbardziej widocznym i dostępnym obszarze, narzuca się sformułowanie, że to największy teatr czasów współczesnych.

We współczesnym sporcie można dostrzec swoistą popkulturową postać religii, jako że „dostarcza on na pozór świeckich, ale (z socjologicznej perspektywy) quasi-religijnych doświadczeń, takich jak doświadczenia świętości i transcendencji, wspólnotowego rytuału i symbolizmu oraz kolektywnego dramatu i emocjonalności" (Rymarczyk 2010, s. 8). Przede wszystkim można i należy postrzegać sport z perspektywy kulturowej. Mieści się wszakże w obrębie części kultury określanej jako kultura fizyczna, stanowiąc jej najbardziej widoczny i najgłośniejszy obszar. W świadomości większej części społeczeństwa sport jest wręcz utożsamiany z kulturą fizyczną, stanowiąc jej jedyny przejaw.

Sport odnosi się do trzech podstawowych form działalności ludzkiej, ponieważ jest zarówno pracą (jest nią z pewnością wysiłek ponoszony dla wysokich osiągnięć sportowych) ${ }^{6}$, nauką (dla opanowania techniki danej dyscypliny), jak i zabawą (jako źródło przyjemności), dlatego w istocie jest w stanie wypełniać w sensie subiektywnym, ale i obiektywnie, znaczną część (całość) ludzkiej egzystencji. Stąd często słyszy się wyznania - „sport (konkretna dyscyplina sportowa) jest całym moim życiem".

Na przestrzeni ponad stu lat swego rozwoju sport dopracował się rozlicznych form, które utrudniają jego zdefiniowanie. Pojęcie sportu nie ma jednoznacznego, wyraźnego desygnatu. W powszechnej świadomości niemal zawsze sport definiowany jest przez obraz jego konkretnej dyscypliny. Te zaś rozwinęły się w liczne grupy: dyscyplin indywidualnych, które z kolei dzielą się na te bez kontaktu z rywalem (kolejno następującymi startami), i te z kontaktem pośrednim oraz bezpośrednim (umożliwiającym np. współdziałanie z partnerami; sporty walki; zespołowe gry sportowe; wieloboje składające się z dyscyplin indywidualnych). Ponadto ze względu na adresata i jego poziom sportowy wyróżnia się sport profesjonalny, zawodowy, wyczynowy, jak i młodzieżowy (stanowiący bezpośrednie zaplecze sportu profesjonalnego) i amatorski, powszechny, masowy (utożsamiany z rekreacją fizyczną) „sport for all”. Inne rozróżnienie, uwzględniające intencje realizatorów, przebiega pomiędzy sportem wyczynowym, którego celem jest przede wszystkim osiągnięcie możliwie najlepszego wyniku oraz zwycięstwo w rywalizacji z innymi

6 Ponadto jest nią wprost w sporcie zawodowym, profesjonalnym z racji korzyści finansowych uzyskiwanych z działalności sportowej. 
zawodnikami, uprawianym zarówno zawodowo, jak i amatorsko, a sportem rekreacyjnym, którego celem jest przede wszystkim dążenie do utrzymania poziomu sprawności fizycznej, zdrowia psychicznego, jak również dobrego samopoczucia. Jeszcze inny podział na sport klasyfikowany i niesklasyfikowany (kwalifikowany i niekwalifikowany), rozróżniając sport profesjonalny (zawodowy), wyczynowy od amatorskiego, powszechnego, uwzględnia dodatkowo poza celem (w pierwszym przypadku to stworzenie widowiska, w drugim - przyjemność wynikająca z jego uprawiania) poziom złożoności organizacji w zakresie regulacji formalnoprawnych (kontrakty zawodowe, stypendia, wynagrodzenie i nagrody za zwycięstwo o znacznej wartości materialnej) i struktury rozgrywek, jak i też dostępności stopnia elitarności (dla osób o specjalnych predyspozycjach, wybitnie utalentowanych i dla każdego - powszechny uprawiany przez przedstawicieli różnych zawodów i profesji).

Złożoność tych rozróżnień, przeprowadzonych w intencji definicyjnego doprecyzowania pojęcia sportu, nakładając się na wcześniej wymienione aspekty zjawiska sportu, dodatkowo komplikuje i w zasadzie uniemożliwia jasne i jednoznaczne jego postrzeganie i zdefiniowanie. Czy zatem sport to pojęcie niedefiniowalne, bo nieposiadające konkretnego desygnatu lub posiadające zbyt wielką ich liczbę? Odpowiedź twierdząca na to pytanie stawia uczestników dyskusji o jednym z najbardziej rozpowszechnionych, najbardziej widocznych i głośnych we współczesnym świecie zjawisk wobec zasadniczego problemu - o czym mówimy? Wydaje się, że wyjściem z tej patowej sytuacji jest cząstkowe, kolejne definiowanie poszczególnych obszarów składających się na zjawisko sportu.

Sport jako zjawisko powszechne we współczesnym świecie, bo występujące wszędzie, we wszystkich krajach, odnoszące się do wszystkich bez względu na wiek, płeć rasę czy stan zdrowia, a więc posiadające znamiona uniwersalizmu i zarazem elitarne, bo dla „ludzi posiadających odpowiednie predyspozycje somatyczno-motoryczne (somatyczno-perfekcjonistyczne)", przejawiające się w wielkiej liczbie zróżnicowanych, niewiele mających ze sobą wspólnego, precyzyjnie skodyfikowanych form. Można jednak wskazać na elementy wspólne dla wszystkich jego przejawów. Występują one w zasadzie bezwyjątkowo, scalając go, definiują, umożliwiając tym samym dyskusję i wszelkie analizy.

$\mathrm{Na}$ taki element naprowadza bardzo użyteczny podział sportu dokonany przez Henryka Grabowskiego uwzględniający rolę, jaką odgrywa on w życiu jednostki (kryterium motywacyjne). Sport, według niego, może być rozumiany jako: a) widowisko (sport spektatorski, pasywny); b) środek realizacji celów pozasportowych - wychowawczych, zdrowotnych, rekreacyjnych - równoznaczny z wszelką aktywnością ruchową (sport instrumentalny, heteroteliczny); c) jako wartość sama dla siebie (sport autoteliczny) (Grabowski 1987, s. 36). W podziale tym uwagę zwraca wyróżnienie aspektu sportu, przez który (za pomocą którego) ze sportem styka się zasadnicza, największa część jego uczestników. W ogóle wyróżnienie takiego obszaru sportu - nazwanie go sportem, jest samo w sobie fundamentalnym wkładem w dyskusję i poznanie tego fenomenu XX wieku, jakim jest zjawisko sportu. 


\section{Widowisko sportowe jako przedmiot analizy}

Widowisko sportowe można analizować z różnych pozycji - historycznej, aksjologicznej, psychologicznej, społecznej. W książce Widowisko sportowe. Analiza psychospołeczna Cz. Matusewicz dokonuje ciekawego spostrzeżenia co do genezy i rodowodu sportu, pisząc: „W bogatej historii widowisk sportowych uwidacznia się ich związek z religią, polityką, ekonomią i strukturą społeczną, z arystokratycznym stylem życia i ruchem robotniczym, z dominacją mężczyzn w życiu społecznym” (Matusewicz 1990, s. 7). Widowisko sportowe określa jako „wielofunkcyjne zdarzenie społeczne" i wymienia te funkcje. Są to: funkcja zabawowa (widowisko sportowe bywa pretekstem do zabawy, fiesty dla społeczności, na terenie której jest ono organizowane); funkcja katharsis (może służyć do rozładowywania napięć społecznych); funkcja propagandowa (dla propagowania treści pozasportowych, np. politycznych); funkcja ekonomiczna (szczególnie w odniesieniu do niektórych dyscyplin sportowych - popularnych lub/i prestiżowych); funkcja estetyczna (dla zaspokojenia potrzeb estetycznych widzów - w założeniu przez cały sport bez różnicowania na dyscypliny, przypisując wartości estetyczne samej rywalizacji sportowej); funkcja sportowa (odmiennie od pozostałych, ukierunkowana na zawodnika dla wsparcia jego wysiłku w walce i rywalizacji - prawdopodobnie równoznaczna z dopingiem); funkcja rekreacyjna (prawdopodobnie w odróżnieniu od pierwszej wymienionej funkcji zabawowej odnosi się do jednostki, nie zaś do zbiorowości).

Powyższy wykaz funkcji widowiska sportowego swym charakterem i zawartością zbliżony jest do znanych prób skatalogowania wartości przypisywanych całemu zjawisku sportu. Nic zresztą w tym dziwnego, wszak widowisko sportowe to integralna składowa sportu, wartości zaś wskazują na określone potrzeby, które przez nie są zaspokajane, spełniając konkretne już funkcje. Ten tor poszukiwań wydaje się zatem naturalny, co więcej, wskazuje na możliwości alternatywnych analiz i podejść.

Jako kategoria sportu, jego wyznacznik i cecha, i jednocześnie ten jego obszar, przez który sport jest odbierany przez zdecydowanie największą część ludzi, widowisko sportowe zasługuje na szczegółowy opis. Przedmiotem pogłębionej refleksji teoretycznej uczyniono widowisko sportowe jako samodzielną rzeczywistość i fakt społeczny, choć z definicji zawierające się w sporcie - stanowiące jego definiens. Celem jest próba systematyzacji poszczególnych wymiarów widowiska sportowego, ich zdefiniowanie we wzajemnych powiązaniach i zależnościach.

\section{Widowisko sportowe jako największy współczesny teatr}

Najwspanialszy, pomnikowy sposób ukazania istoty widowiska sportowego, tego, co mu towarzyszy, emocji, jakie wywołuje, w szczególnej, bo poetyckiej formie, zawarty jest w wierszu Match footballowy Kazimierza Wierzyńskiego ${ }^{7}$, jed-

7 Kazimierz Wierzyński (1894-1969), jeden z najpoczytniejszych poetów międzywojnia, założyciel, wspólnie z Julianem Tuwimem, Antonim Słonimskim, Jarosławem Iwaszkiewiczem i Janem 
nego z najpoczytniejszych poetów dwudziestolecia międzywojennego, publicystę sportowego i redaktora naczelnego „Przeglądu Sportowego” w latach 1926-1931. Wiersz ten wraz z innymi, pod wspólnym tytułem Laur olimpijski, przyniósł autorowi złoty medal olimpijski w 1928 roku na Igrzyskach w Amsterdamie - pierwszy dla polski złoty medal olimpijski w dziedzinie sztuki ${ }^{8}$.

Poetycka forma relacji z rozgrywanego (czas teraźniejszy jest tu istotny) właśnie meczu piłkarskiego dostarcza kapitalnego opisu i charakterystyki istoty widowiska sportowego. Pierwsza z sześciu zwrotek wiersza zawiera fenomenalną w swej warstwie (analizie) psychologicznej, a poetycko najwyższych lotów formie, definicję widowiska sportowego:

Oto tu jest największe Colosseum świata,

Tu serce żądz i życia bije najwymowniej,

Tu tajemny sens wiąże i entuzjazm brata

Milion ludzi na wielkiej rozsiadłych widowni ${ }^{9}$.

Już w pierwszym wersie pierwszej zwrotki autor stwierdza, że widowisko sportowe jest największym, grupującym największą widownię teatrem - „największe Colosseum świata". Z kolejnych dowiadujemy się, że to w tym miejscu najmocniej bije serce wszelkiego życia i to tu mamy do czynienia z tajemną siłą zespalającą uczucia, emocje, serca i umysły wielkiej rzeszy zebranych ludzi.

Ten fantastyczny w swej skróconej formie i wymowie opis widowiska sportowego, w tym przypadku tego, co się dzieje na trybunach stadionu piłkarskiego, kojarzący je z największą antyczną areną widowiskową - Koloseum, wejdzie na stałe do kanonu klasyki sportu. Zacznie on być nazwany największym teatrem XX wieku.

Skojarzenie sportu (widowiska sportowego) z największym antycznym teatrem jest nie tylko trafne i pięknie poetycko przekazane, ale też jest całkowicie uzasadnione merytorycznie. Współcześnie rywalizacja sportowa, w tym szczególnie ważne mecze piłkarskie rozgrywane są na oczach tysięcy osób na stadionach i milionów przed telewizorami. Pomijając transmisje telewizyjne zawodów, których to Wierzyński jeszcze nie znał, sam stadion z wielotysięczną widownią dalece wyrasta pod tym względem ponad każdy wielki teatr.

Lechoniem, grupy poetyckiej Skamander, polski patriota, członek Drużyn Strzeleckich, „Zarzewia” młodzieżowej organizacji paramilitarnej i ochotnik w szeregach Legionu Wschodniego generała Hallera, w wolnej Polsce dwudziestolecia międzywojennego - publicysta sportowy i redaktor naczelny „Przeglądu Sportowego” (w latach 1926-1931), „mistrz olimpijski słowa” - zdobywca złotego medalu olimpijskiego w konkursie sztuki za cykl wierszy (m.in. Defilada atletów, $100 \mathrm{~m}$, Skok o tyczce, Panie na start!, Nurmi, Dyskobol, Bieg na przełaj...) pod wspólnym tytułem Laur olimpijski (oceniony najwyżej spośród 40 prac nadesłanych z 19 krajów), emigrant polityczny w czasach Polski Ludowej, zmarł w Londynie.

$8 \mathrm{Na}$ igrzyskach w Los Angeles pierwszy złoty medal olimpijski zdobyła Halina Konopacka w rzucie dyskiem.

9 Pierwodruk: „Dziennik Warszawski” 1927, „Tygodniowy Dodatek Ilustrowany” nr 1. Za: I. Bittner, A. Bryk, O sporcie i kulturze fizycznej, poezji i medycynie czyli o etosie ciała ludzkiego, Wydawnictwo Uniwersytetu Łódzkiego, Łódź 2003, s. 133. 
Na tym samym poziomie trafności autor opisuje uczucia i emocje towarzyszące widowisku sportowemu, jak choćby w końcówce czwartej zwrotki: „Trybuny tracą oddech, cały stadion kona", i w całej ostatniej zwrotce:

\footnotetext{
Widownia oszalała, krzyczy, bije brawo,

Półkole trybun płonie niczym aureola

I jak wielka tęsknota za zwycięską sławą

letni okrzyk stadionu: gola, gola, gola!
}

Natomiast w innym miejscu, w piątej zwrotce, czytamy:

I pokażcie mi teraz - gdzie, w jakich teatrach

Milion widzów wystrzeli takim wielkim głosem (...).

\section{Widowisko sportowe jako przedmiot i inspiracja dla sztuki}

Sport, rywalizacja sportowa stanowi przedmiot inspiracji różnych dziedzin twórczości artystycznej: poezji, literatury, rzeźbiarstwa, malarstwa, muzyki czy architektury. Wiersz Match footballowy Kazimierza Wierzyńskiego, będący dowodem na związki sportu ze sztuką, a konkretnie na inspirujące oddziaływanie sportu na sztukę, jest jednocześnie jednym z najwspanialszych pomników łączących polską kulturą fizyczną i polską poezję.

Inspiracją i tematem utworów lirycznych są podniosłość i patos związane z sytuacjami i stanami skrajnymi walki sportowej (często przy okazji zmagań zawodników pada sformułowanie: „walka o wszystko”), a także takimi, w których bezpośrednio zagrożone jest zdrowie, a nawet życie zawodników. Oddanie nastroju towarzyszącego zmaganiom sportowym - w tym takich emocji, jak: napięcie psychiczne wynikające z koncentracji na (w danym momencie) najważniejszym celu, stan wyczekiwania na ruch zawodnika (własnego lub rywala), krzyk radości lub jęk zawodu czy też groza nieuchronnie nadciągającej porażki - często staje się przedmiotem opisów poetyckich.

Osobną dziedzinę obecną w sztuce lirycznej stanowi ciało ludzkie w ruchu. Definicyjna aktywność ruchowa człowieka jako istota zjawiska sportu ma swoje odniesienie - przyczynę, przebieg i skutek - w ciele ludzkim. Ukazanie w słowach dynamiki, precyzji, płynności czy w końcu zwykłego naturalnego piękna ciała ludzkiego w najróżniejszych pozach i ruchu stanowi w tym przypadku zasadniczy przedmiot opisów literackich. Współgrają z nimi wysiłek, zmęczenie i inne stany związane z walką sportową.

Sport w sztuce rzeźbiarskiej zawsze kojarzony jest z dyskobolem Myrona, jednego z najwybitniejszych rzeźbiarzy greckich żyjącego w $\mathrm{V}$ wieku p.n.e. Aktywność sportowa jako temat w rzeźbiarstwie sprowadza się do próby uchwycenia piękna ciała ludzkiego w ruchu, jego dynamiki odwzorowywanej w rzeźbie mięśni. Dzieło Myrona przedstawia atletę w dynamicznej pozycji, jaką się przybiera 
podczas rzutu dyskiem, jednej z pięciu konkurencji olimpijskich pentatlonu ${ }^{10}$, najbardziej klasycznej, znanej już w czasach Homera i uważanej przez starożytnych Greków za najbardziej sportową. Do naszych czasów przetrwała rzymska kopia tej rzeźby.

Równie odległą przeszłość ma sport w malarstwie. Słynne amfory panatenajskie ozdobione malowidłami atletów i patronki Aten, bogini Ateny, wypełnione drogocenną oliwą, stanowiły rodzaj trofeum, o które rywalizowali zawodnicy (w konkurencji przedstawionej na danej amforze). Nagroda taka miała wymiar zarówno symboliczny, jak i materialny, a przyznawana była zgodnie z grecką tradycją tylko zwycięzcom.

Obecność sztuki w sporcie łączona jest najczęściej z Olimpijskimi Konkursami Sztuki i Literatury. W odniesieniu do igrzysk w starożytności najczęściej wspomina się o imprezach towarzyszących, w których również rywalizowano, takich jak występy poetów, pisarzy, mówców, filozofów, polityków, muzyków (w grze na lirze, flecie, trąbie) i śpiewaków. Jednak nie ma pewności co do zakresu ich udziału na przestrzeni historii igrzysk. Pewną informacją jest pojawienie się konkursu trębaczy i heroldów na 96 igrzyskach olimpijskich w 396 roku p.n.e. Wiarygodne, bo dobrze udokumentowane dane na temat konkursów sztuki organizowanych w trakcie igrzysk pochodzą z czasów panowania Nerona. W igrzyskach 211 olimpiady w 67 roku n.e. uczestniczył sam Cezar, zwyciężając w aż sześciu konkursach sztuki i wyścigu dwukołowych wózków ciągniętych przez muły, którego zresztą nie ukończył. Wydarzenia te (a przypomnijmy, że datę igrzysk przesunięto o dwa lata - właściwy termin to rok 65 - tak by Neron po odpowiednich przygotowaniach mógł wziąć w nich udział, samym sędziom zaś zapłacono 250 tysięcy drachm za pomoc w zwycięstwie) świadczą o ostatecznym upadku idei igrzysk ${ }^{11}$.

Olimpijski Konkurs Sztuki i Literatury na igrzyskach nowożytnych, rozgrywanych od 1896 roku, pojawi się z inicjatywy wskrzesiciela idei igrzysk barona Pierre'a de Coubertina, w Sztokholmie - w ramach V olimpiady ${ }^{12}$. Próba ich wprowadzenia do programu igrzysk pojawiła się już cztery lata wcześniej (sam pomysł został przedstawiony w 1906 roku), jednak bez powodzenia z braku zainteresowania i zaangażowania ze strony organizatorów Igrzysk w Londynie w 1908 roku. Ostatecznie Konkurs Sztuki i Literatury w programie igrzysk olimpijskich ery nowożytnej znajdzie się na kolejnych siedmiu olimpiadach: w Sztokholmie (1912), Antwerpii (1920), Paryżu (1924), Amsterdamie (1928), Los Angeles (1932), Berlinie (1936), Londynie (1948), po której, z inicjatywy ówczesnego przewodniczącego MKOI Sigfrida Edströma, zostanie usunięty.

Program Olimpijskiego Konkursu Sztuki i Literatury obejmował różne dziedziny twórczości artystycznej, jak: poezja, epika, rzeźba, malarstwo, architektura oraz muzyka. Polscy twórcy inaugurują swój udział w konkursie na igrzyskach

\footnotetext{
10 Pozostałe to: bieg, skok w dal z ciężarkami, rzut oszczepem i zapasy.

11 Będą jeszcze organizowane do 393 roku, kiedy to zostaną zakazane przez chrześcijańskiego cesarza Teodozjusza I.

12 Pierre de Coubertin sam niejako zainaugurował Olimpijski Konkurs Sztuki i Literatury na igrzyskach 1912 r. w Sztokholmie, jako że występując pod podwójnym pseudonimem, zdobył złoty medal w konkursie literatury za wiersz Oda do sportu.
} 
w 1928 roku w Amsterdamie (start polskiej reprezentacji nastąpił cztery lata wcześniej w Paryżu), od razu odnosząc spektakularny sukces w postaci złotego medalu dla Kazimierza Wierzyńskiego w dziedzinie poezji. Na tych samych igrzyskach brązowy medal za grafikę przypadnie Władysławowi Skoczylasowi. W kolejnych, w 1932 roku w Los Angeles, złoty medal w dziedzinie rzeźby przyznano Józefowi Klukowskiemu, a srebrny Janinie Konarskiej za grafikę; w 1936 w Berlinie srebrny medal w dziedzinie rzeźby zdobył Józef Klukowski, brązowy za grafikę - Stanisław Ostoja-Chrostowski, a w dziedzinie prozy Jan Parandowski; w 1948 w Londynie złoty medal w dziedzinie muzyki otrzymał Zbigniew Turski.

Najbardziej spektakularne przejawy mariażu sportu i sztuki obserwujemy podczas zwyczajowych już ceremonii otwarcia wielkich imprez sportowych, w szczególności igrzysk olimpijskich. Ceremonie takie organizowano już w starożytności, i tak jak każde święto religijne (były nimi starożytne igrzyska olimpijskie) charakteryzowały się one podniosłą atmosferą, a towarzyszyły im uroczystości w świątyni Zeusa połączone ze składaniem ofiar Zeusowi i bogom - patronom miast reprezentowanych na igrzyskach. Kolejne punkty uroczystości to zaprzysiężenie zawodników (przysięga dotyczyła przestrzegania etyki olimpijskiej - walki zgodnej z regulaminem, jak również deklaracji co do rzetelnego przygotowania się do zawodów), ogłoszenie imion zawodników biorących udział w poszczególnych konkurencjach, zapalenie znicza olimpijskiego oraz konkursy trębaczy i heroldów.

Współczesne ceremonie otwarcia, do złudzenia przypominając tamte, stały się gigantycznymi widowiskami łączącymi różnego rodzaju przekaz artystyczny - światło, obraz, dźwięk. Przygotowywane przez wiele miesięcy, a nawet lat (miasto - organizator igrzysk zna ich termin na osiem lat wcześniej), widowisko artystyczne winno jednocześnie promować olimpijskie wartości uniwersalne (równość, przyjaźń, wzajemny szacunek) i nawiązywać do dorobku kulturalnego gospodarza igrzysk. Oznacza to, że powinno być w najwyższym stopniu oryginalne, zupełnie różne od poprzednich, a nade wszystko - jeszcze wspanialsze, jeszcze bardziej zachwycające. To oczywiście musi kosztować i kosztuje setki milionów dolarów, ale to się nie liczy, gdy w grę wchodzi największa z możliwych promocja miasta, państwa, narodu, jego kultury i tożsamości.

Kolejni organizatorzy igrzysk rywalizują, prześcigając się w tworzeniu coraz bardziej wspaniałego widowiska. Ta (w pełnym tego słowa znaczeniu) rywalizacja, chociaż nie jest punktowana, to jednak w najdrobniejszych szczegółach jest analizowana i odnotowywana jako jedno z najistotniejszych wydarzeń największej imprezy sportowej świata. Otwarcie igrzysk olimpijskich jako odrębna od samych zawodów sportowych jakość stało się tym samym jednym z największych wydarzeń artystycznych w skali całego globu. W świecie przedstawień artystycznych nie istnieje nic o większym rozmachu i zasięgu. Łącząc różne dziedziny przekazu artystycznego, sięga się w nim do całego dziedzictwa kulturowego, włączając w nie najwspanialsze dzieła.

Z olimpiady na olimpiadę miliardy widzów na całym świecie obserwują coraz wspanialsze widowisko artystyczne, perfekcyjnie wyreżyserowane i w najwyższym stopniu niepowtarzalne. Ma się ono kojarzyć z jednym miejscem i jednym momentem w historii. Ten wyścig zdaje się nie mieć końca, trwa od dziesięcioleci, a jego początek należy wiązać z tym, co się wydarzyło podczas XI Igrzysk 
Olimpijskich w Berlinie w 1936 roku. To w państwie Hitlera dostrzeżono po raz pierwszy potęgę reklamy i autopromocji, jaka wiąże się z organizacją igrzysk i sportem w ogóle i - perfekcyjnie tę potęgę wykorzystano.

$\mathrm{Na}$ tych igrzyskach ma miejsce najbardziej spektakularny debiut w sztuce, dla którego inspiracją stało się widowisko sportowe. Chodzi o pierwszy pełnometrażowy film dokumentalny Olympia wyreżyserowany przez Leni Riefenstahl ${ }^{13}$. Zmagania sportowców posłużyły za materiał do stworzenia dzieła, które wprawiło w autentyczny zachwyt publikę na całym świecie. „The Times” napisał o nim, że jest „wizualnie zachwycający", a kilka scen nazwał tak niezwykłymi, że aż abstrakcyjnymi.

Wyjątkowość filmu polega na zastosowaniu nowatorskich technik rejestracji obrazu związanych z nietypowym ustawieniem kamery i oświetleniem (w tym zdjęcia pod światło), połączonych z dużą dbałością o wysoką jakość techniczną zdjęć i montaż poszczególnych scen. Nowatorski charakter formalny dzieła, jego kunszt i tematyka, pozwalają mówić o wielkim wydarzeniu w sztuce - narodzinach filmu dokumentalnego o tematyce sportowej ${ }^{14}$.

Film powstał na zamówienie ${ }^{15}$ w 1938 roku. Składa się z dwóch części: Olimpiada część 1 Święto Narodów (Olympia 1. Teil - Fest der Völker) - 115 min, zrealizowanej z myślą o widzach niemieckich, i Olimpiada część 2 Święto Piękna (Olympia 2. Teil - Fest der Schönheit) - 88 min, adresowanej głównie do odbiorcy zagranicznego. Film opowiadający o Letnich Igrzyskach Olimpijskich w Berlinie w 1936 roku jest także wspaniale wyreżyserowaną apoteozą wielkości (możliwości) Niemiec. Przeszedł do historii jako jeden z najważniejszych filmów wszechczasów, a jego autorka Leni Riefenstahl została nagrodzona złotym medalem olimpijskim przez Międzynarodowy Komitet Olimpijski ${ }^{16}$.

Widowisko sportowe stanowiąc kwintesencję zjawiska sportu pozostaje w ścisłej relacji z różnymi dziedzinami sztuki, jest przedmiotem i inspiracją dla poezji, literatury, rzeźbiarstwa, malarstwa, muzyki, a także najnowszej z nich, filmu. Stanowi dla nich atrakcyjny temat, rozszerzając $w$ istotnym zakresie perspektywę twórczości artystycznej. Właściwości widowiska sportowego - szczególnie

13 Leni Riefenstahl (Berta Helene Amalie „Leni” Riefenstahl) (1902-2003) - słynna w hitlerowskich Niemczech reżyserka filmowa, wcześniej tancerka i aktorka, twórczyni słynnego dokumentu z letnich igrzysk olimpijskich w Berlinie w 1936 roku Olimpia, prekursorka nowoczesnej rejestracji obrazu filmowego, którego wyznacznikami były nowatorskie ujęcia zdjęciowe i montaż poszczególnych scen podporządkowane oryginalnej i unikalnej estetyce nastawionej na wywołanie pożądanych wrażeń i emocji, w całości składające się na perfekcjonizm realizacji.

14 Leni Riefenstahl jest autorką legendarnego dokumentu ze zjazdu Partii Narodowosocjalistycznej (parteitagu) w Norymberdze w 1934 roku pt. Triumf woli.

15 Powstał w 1936 roku z materiału nakręconego podczas igrzysk, premiera odbyła się 20 IV 1938 roku. Według autorki film został zlecony przez Międzynarodowy Komitet Olimpijski, podczas gdy pozostałe źródła wskazują na Hitlera jako bezpośredniego inspiratora. Znając realia tamtego czasu, to, jak funkcjonowało państwo niemieckie, a także mając na uwadze relacje nazistów ze wskrzesicielem, a w tym czasie honorowym prezydentem igrzysk olimpijskich Pierre'em de Coubertinem, i osobistą sympatię Riefenstahl do Hitlera (swego czasu miała wyznać: „Dla mnie Hitler jest największym człowiekiem, jaki kiedykolwiek żył”), można przyjąć, że nie było sprzeczności pomiędzy tymi wersjami.

16 Pokazywany był na całym świecie po usunięciu z niego trzyminutowego fragmentu z Hitlerem, na co zgodę w 1955 roku wyraziła autorka. Ta sama wersja była też emitowana w zachodnioniemieckiej telewizji i w kinach na całym świecie. 
te odnoszące się do aspektu emocjonalnego walki sportowej, jak również jej warstwy symbolicznej, związanej z ludzką egzystencją, fascynacją jej wielkością i znikomością zarazem - stanowią niewyczerpalne źródło zainteresowania różnych dziedzin twórczości artystycznej światem sportu. Zachodzi również relacja odwrotna, szczególnie w przypadku przekazu filmowego jako zasadniczego kanału popularyzacji sportu w najróżniejszych jego odmianach. Transmisja telewizyjna relacji (obrazu) z widowiska sportowego jest podstawową pożywką w sensie dosłownym i w przenośni, bez której współczesny sport nie może funkcjonować, rozwijać się i zapewne w ogóle istnieć. Płynący stąd wniosek co do perspektyw współegzystencji sportu i sztuki jest nader optymistyczny.

\section{Widowisko sportowe jako przestrzeń wywoływania i zaspokajania potrzeby emocji - jako „fabryka” emocji i działalność usługowa zaspokajająca ludzkie potrzeby w tym zakresie}

O atrakcyjności sportu dla przestrzeni medialnej decyduje jego najbardziej widoczna cecha - zdolność budzenia i zaspokajania potrzeby emocji. Widowisko sportowe jest obecnie największą, o najszerszym zasięgu przestrzenią wywoływania najsilniejszych emocji. Pod względem skali i poziomu generowanych emocji, np. podczas ważnego, decydującego (o mistrzostwie) meczu piłkarskiego, w którym uczestniczy „nasza” drużyna, widowisko sportowe daje się porównać jedynie do sytuacji w czasie wojny (działań wojennych), gdzie występuje bezpośrednie zagrożenie zdrowia i życia.

Sport w swoim wymiarze widowiskowym, szczególnie w odniesieniu do gier zespołowych na czele z piłką nożną, jest istną „fabryką emocji”, produkującą wrażenia na potrzeby najszerszego kręgu odbiorców, w uporządkowanym, stosunkowo bezpiecznym współczesnym świecie. To właśnie uporządkowanie, poczucie stabilizacji i bezpieczeństwa, z jakimi mamy dzisiaj do czynienia, stanowiąc skądinąd jedną z najważniejszych potrzeb człowieka, stają się źródłem budzenia potrzeby o przeciwstawnym wektorze - potrzeby emocji związanych z niepewnym rezultatem, z możliwością osiągnięcia wielkiego „zysku”, jakim jest zwycięstwo „naszych”, lub poniesienia dotkliwych „strat”, w tym przypadku jedynie moralnych związanych z zawiedzionymi nadziejami.

To swoisty paradoks, że jedno z cenniejszych osiągnięć cywilizacyjnych i cel wielu kosztownych zabiegów, jakim jest pokój, poczucie bezpieczeństwa i stabilizacji życiowej, rodzi deficyt innej, jak się okazuje, wartości - jakimi są niepewność i emocje związane z brakiem bezpieczeństwa. Dotyczy to w naturalny sposób przede wszystkim ludzi młodych (z racji uwarunkowań biologicznych, jak i po części względów kulturowych - w zdecydowanie większym stopniu mężczyzn niż kobiet), w naturalny sposób predestynowanych do funkcjonowania w takich warunkach.

Zapotrzebowanie na emocje, prowokowane ustabilizowaną, jednostajną, szarą egzystencją, jest także zróżnicowane osobniczo. U pewnej niewielkiej części osób zapotrzebowanie to jest bardzo realne i wyraża się w poszukiwaniu 
sposobów jego zaspokojenia. Efektem takich poszukiwań są zachowania ekstremalne. Sport jest właściwym miejscem zachowań ekstremalnych - jako taki z nich się wywodzi. Jest tym samym przestrzenią dostarczającą emocji w najszerszym asortymencie stosownie do swej własnej różnorodności. Co więcej, poprzez stanowiące jego integralną składową widowisko sportowe udostępnia niejako swoją przestrzeń emocji niczym nielimitowanej liczbie odbiorców.

Emocjonalny wymiar widowiska sportowego wpisuje się w jego wymiar rekreacyjny. Emocje towarzyszące każdym zawodom sportowym, w szczególności gdy są wsparte indywidualnymi zainteresowaniami, stanowiąc ich istotę, są jednocześnie zasadniczym motywem przejawianych zainteresowań sportowych i preferowanych form zachowań relaksacyjnych przeważającej części mężczyzn. Niepodważalny prym wiedzie w tym obszarze piłka nożna, grupująca największą widownię bezpośrednio na stadionie i pośrednio przed odbiornikami telewizyjnymi.

\section{Rekreacyjny wymiar widowiska sportowego}

Sport w swym wymiarze widowiskowym jest przestrzenią dla rekreacji setek milionów osób na całym świecie. Jako największa arena we współczesnym świecie sport jest największym producentem rozrywki, wręcz gigantem dostarczającym obrazów i wrażeń w każdych zgłaszanych popytem ilościach i na niespotykaną w innych dziedzinach skalę. Cała istniejąca, szeroko rozumiana infrastruktura sportu zorientowana jest na produkcję i dostarczanie rozrywki. Składają się na nią baza materialna w postaci obiektów, urządzeń i sprzętu sportowego, jak i niematerialna, czyli poszczególne dyscypliny sportu ze swoimi regulacjami/ przepisami i systemem rozgrywek. Ponadto tworzą ją także instytucje sportowe (stowarzyszenia, kluby, związki, federacje), jak i instytucje w obrębie administracji różnych szczebli oraz regulujące funkcjonowanie całości wszelkiego rodzaju formalnoprawne zapisy. A nade wszystko media, zarówno te funkcjonujące jako dodatek do niemal każdego dziennika prasowego czy programu telewizyjnego, jak i te wyspecjalizowane w relacji i transmisji zawodów sportowych czy konkretnej dyscypliny sportowej.

Analiza różnych aspektów sportu jako zjawiska społecznego o stale zwiększającym się zasięgu pod kątem społecznego znaczenia i oddziaływania wskazuje na jego zasadniczą, dominującą funkcję, jaką jest dostarczanie rozrywki, co realizuje się za pośrednictwem widowiska sportowego. Dzięki niemu dociera on do niemal każdego człowieka na kuli ziemskiej, stając się ważnym obszarem funkcjonowania coraz większej liczby osób, jak i całych grup społecznych. Ten obszar to odpoczynek i rekreacja realizujące się w rozrywce i zabawie. Jako reakcja na pozostałe - naukę i pracę, wchodzi w skład potrzeb człowieka.

Widowisko sportowe zdobyło sobie pozycję niepodważalnego lidera w dostarczaniu rozrywki, czyni to na największą skalę, docierając do największej liczby odbiorców za pośrednictwem mediów. Interesująca w tym kontekście jest refleksja nad historycznym aspektem realizacji potrzeby rekreacji i rozrywki przed „epoką sportu”. Dynamiczny, wręcz eksplozywny rozwój zjawiska sportu w XX 
wieku skłania do wniosków o złożoności potrzeb człowieka w zakresie rekreacji, sposobach ich zaspokajania przez różne jej formy i w tym wszystkim o roli widowiska sportowego, która nabiera wymiaru cywilizacyjnego. Refleksja taka wybiega znacznie poza obszar sportu, z którym łączy ją wspomniany powyżej rekreacyjny wymiar widowiska sportowego.

Historyczny wątek prowadzonych tu analiz nad rekreacyjnym wymiarem widowiska sportowego musi, siłą rzeczy, zmierzać do antycznych prapoczątków związanych z igrzyskami olimpijskimi. Zapewne one również odpowiadały na to swoiste zapotrzebowanie społeczne wyrażane głośno w słynnym zawołaniu „panem et circenses". Z tej perspektywy najlepiej widać społeczny zasięg pojęcia rekreacji - jego odniesienie do zjawisk społecznych, ekonomicznych i politycznych. Jednocześnie odnosząc pojęcie rekreacji do jednostki, z definicji kojarzymy ją z wypoczynkiem mającym swe dobroczynne skutki dla zdrowia.

\section{Zdrowotny wymiar widowiska sportowego}

Potoczne sformułowanie „Sport to zdrowie” jest najczęściej podawaną swoistą definicją sportu. Istotnie, sport pozostaje w bliskiej relacji do zdrowia, choć nie takiej jak przedstawia to powyższe hasło.

Sport, ten kwalifikowany, wyczynowy, zawodowy, a więc ten na najwyższym poziomie, realizowany na granicy ludzkich możliwości, stwarza szczególnie wysokie wymagania wobec zdrowia, i najczęściej oznacza eksploatację stosowną do jego poziomu. Zdrowie dla sportu tym samym to niezbędny warunek, podstawa jego realizacji. Zasoby zdrowotne jednostki określają jej bazowe predyspozycje do sportu.

Zdrowotny wymiar sportu, w sensie budowania potencjału sprawnościowego poszczególnych układów i narządów, odnosi się do części dyscyplin i to na etapie szkolenia ogólnego. Wraz z kontynuacją szkolenia na poziomie specjalnym (poziomie mistrzostwa sportowego) możliwości adaptacyjne organizmu osiągają swoje apogeum. Tu kończy się stymulujący wpływ wysiłku fizycznego na sprawność, a zaczyna okres wyłącznego wykorzystywania jej do celów sportowych, jakimi są walka o zwycięstwa, medale, puchary itp. W sensie fizjologicznym oznacza to eksploatację fizyczną z negatywnymi skutkami dla zdrowia wyrażającymi się w przeciążeniach w obrębie najsilniej, w danej dyscyplinie sportu, angażowanych struktur (mięśni, wiązadeł oraz całych układów). Eksploatacja taka jako naturalna konsekwencja skrajnych i wąsko ukierunkowanych obciążeń (takie są w sporcie) postępuje tym szybciej, im bardziej przedmiotowo traktowany jest zawodnik (jako „maszyna” do zwyciężania), im gorsza jest opieka biomedyczna, którą jest otaczany.

Relację sportu i zdrowia - zdrowotny wymiar sportu - obrazują w pewnym stopniu swoiste jednostki chorobowe, takie jak łokieć tenisisty, kręgosłup gimnastyczki, bark piłkarza ręcznego, kolano biegacza i in., co coraz częściej wykorzystywane jest do krytyki wyczynu sportowego. Krytyka ta, posiłkując się stale dostarczanymi „dowodami wpływu sportu na zdrowie”, nie uwzględnia sportu w całościowym wymiarze i ma charakter jednostronnie negatywnie ukierunkowany. 
Widowisko sportowe to swoista emanacja zdrowia w jego ekstremalnym wymiarze, z perspektywy skrajnych, granicznych możliwości człowieka. Daje ono możliwość uczestniczenia w skrajnych doznaniach - odczuwaniu tegoż zdrowia jednocześnie w swej wielkości i ułomności. Tak się dzieje wtedy, gdy działając na granicy - i poza granicami - ludzkich możliwości, dochodzi nagle do nagłego „rozstania się ze zdrowiem”. Można przyjąć, że w części to właśnie możliwość doświadczenia tej chwili przez obserwację stanowi istotny motyw dla znacznej części widowisk i widzów. Taka sytuacja wydaje się szczególnie widoczna w sportach motorowych, gdzie obserwuje się, jak dalece możliwości psychoruchowe prezentowane przez kierowców rajdowych są w stanie chronić ich przed bardzo realnym niepowodzeniem, oznaczającym w tym przypadku tylko najpoważniejsze konsekwencje dla zdrowia i życia.

\section{Ekonomiczny wymiar widowiska sportowego}

O sporcie możemy mówić na płaszczyźnie ekonomicznej. Zjawisko, które ma taki zasięg, nie może funkcjonować w oderwaniu od materialnych podstaw. Czerpiąc pieniądze na swoje funkcjonowanie, generuje zyski dla ludzi zaangażowanych w działalność sportową, jest jednocześnie wielkim klientem rynku towarów i usług, jak i pracodawcą i żywicielem dla setek tysięcy swoich uczestników.

Widowisko sportowe, które stanowi zasadniczy aspekt, esencję zjawiska sportu, jest jego rdzeniem, osnową, z racji swojego charakteru eksponuje czynnik ekonomiczny w największym stopniu. Obecnie każda impreza sportowa, od zawodów towarzyskich o zasięgu regionalnym do tych o randze centralnej, jak mistrzostwa krajowe, Europy, mistrzostwa świata, wszelkie puchary i mitingi - to przedsięwzięcia w takim samym stopniu sportowe, jak i biznesowe (ekonomiczne). Widowiska sportowe stanowią określoną inwestycję gospodarczą. Z tej perspektywy różnice między nimi sprowadzają się tylko do zakresu potencjalnych odbiorców towarów i usług oraz skali możliwego zysku. Jako takie dysponują one skrupulatnie zaplanowanymi budżetami, zawierającymi przychody z transmisji od wielkich stacji telewizyjnych, reklam od wielkich koncernów, jak i wydatki, w przeważającej części na rzeczy niemające żadnego związku z konkretną rywalizacją sportową.

Imprezom sportowym takim jak igrzyska olimpijskie od wielu lat towarzyszą gigantyczne w swym rozmachu widowiska otwarcia igrzysk. Są to jednorazowe imprezy artystyczne, kończące się wraz ze swoją premierą, kosztujące setki milionów dolarów. Wszystko po to, by przyciągnąć jeszcze większą rzeszę odbiorców, ustanowić kolejny rekord widowni. Istotnie, próżno by szukać realnego pod tym względem konkurenta imprez sportowych. Transmitowane na bieżąco do niemal wszystkich krajów świata ogląda ponad połowa mieszkańców globu.

Organizacja takich imprez sportowych przyznawana jest więc tym, którzy mogą jej podołać, przez niezależną międzynarodową organizację typu MKOI czy federację w konkretnej dyscyplinie sportu (UEFA, FIFA). Kryteria przydzielania 
organizacji imprez sportowych są oczywiście bardziej złożone i, jak donoszą w ostatnim czasie media, mocno niejasne. Gwarancja odpowiednio wysokiego zysku dla samego zleceniodawcy (federacji, związku), ocierająca się o korupcję, jako kryterium pozytywnej decyzji wymieniana jest na pierwszym miejscu.

Kolejka chętnych do organizacji zawodów sportowych różnych szczebli jest długa. Powodowane jest to kalkulacją zysków własnych, w tym, w największym stopniu, tych o charakterze wizerunkowym i prestiżowym. Organizator ważnych zawodów sportowych przede wszystkim ma możliwość pokazania się, zaprezentowania swojego dorobku, swoich osiągnięć, swojej kultury. Zysk ten ma szczególnie realny wymiar dla elit rządzących w danym kraju, umożliwia przekaz o dobrej organizacji, sprawnym zarządzaniu państwem, za co ponoszą odpowiedzialność przed społeczeństwem. Nie oznacza to deprecjacji tego typu zysków po stronie całego społeczeństwa, które może czerpać satysfakcję i poczucie dumy narodowej z faktu bycia przez pewien czas w centrum uwagi Europy czy świata.

Jednak w pełni realny zysk z organizacji wielkich imprez sportowych odnosi się do korzyści ekonomicznych i gospodarczych i wiąże się z pozytywnym impulsem w sferze infrastruktury nie tylko sportowej, ale i transportowej (drogi, koleje, transport lotniczy), hotelarskiej, gastronomicznej, związanych z koniecznością zakwaterowania i wyżywienia przyjeżdżających ekip i ich sympatyków, kibiców z różnych krajów.

Kalkuluje się też zyski pośrednie w sferze rozwoju usług i wzrostu produkcji wywołanych popytem konsumpcyjnym, jak również zyski w dłuższej perspektywie, związane z „odkryciem” kraju, regionu. Zakłada się, że za sprawą pozytywnych doświadczeń z pobytu na imprezie sportowej pojawi się chęć powrotu w to miejsce w przyszłości - istnieje więc szansa na zyski ze wzrostu liczby turystów, rozwoju turystyki.

Przyspieszenie inwestycji w infrastrukturę sportową, turystyczną, transportową, wzrost popytu, zwiększenie sprzedaży towarów i usług, w tym usług turystycznych, to realne i dobrze uświadomione zyski z organizacji imprez sportowych. Jednak pobieżna analiza zysków i kosztów organizacji wielkich imprez sportowych (ściślej: doniesień na ten temat - rzeczywiste dane są badawczo niedostępne) wskazuje, że przedsięwzięcia te trudno wiązać z finansowym sukcesem. Na pewno natomiast wiążą się z ogromnymi nakładami, które państwa są skłonne z jakichś przyczyn ponosić. Wszystko wskazuje, że tą przyczyną jest wspomniany już zysk społeczny i polityczny

\section{Społeczny i polityczny wymiar widowiska sportowego}

Sport, jak również to, przez co jest postrzegany, a więc widowisko sportowe, jest ważnym elementem kultury masowej. Jest środkiem przekazu ważnych dla współczesności i przyszłości treści symbolicznych, symbolizuje określony porządek ludzkiej egzystencji, wzajemne relacje - człowieka do samego siebie, do innych ludzi, i szerzej, otaczającej go rzeczywistości. Jest uniwersalnym 
czynnikiem integracji społecznej, tak w wymiarze elementarnym (od najmniejszej grupy sympatyków określonej drużyny, szczególnie w niewielkiej miejscowości), jak i regionu, narodu, państwa, Europy i świata (Krawczyk 2012, s. 34-35). Właściwość ta wynika wprost z wartości emocjonalnych sportu. To na gruncie przeżywanych wspólnie emocji, stanów wielkiej radości i uniesienia po zwycięstwie, jak i przygnębienia i smutku po przegranej, dumy i rozczarowań, wielkiego napięcia i eksplozji uczuć - tworzy się poczucie więzi, a następnie wspólnoty, buduje swoista tożsamość psychologiczna, duchowa i kulturowa. Ten aspekt widowiska sportowego sprawia, że jest ono wyjątkowym miejscem realizacji czynnika narodowego w życiu społecznym. Widowisko sportowe jest też miejscem sprzyjającym kształtowaniu się, rozwojowi, jak i pielęgnacji uczuć narodowych i patriotycznych.

W sposób niezwykle wymowny i piękny jednocześnie zagadnienie społecznie integrującej i państwowotwórczej roli sportu rozwija dyrektor Departamentu Politycznego MSZ w międzywojennej Polsce płk I. Matuszewski. W artykule z 13 XI 1926 roku $^{17}$ pisze: „I otóż zmagania sportowe są dziś jeśli nie u nas jeszcze, to na szerokim świecie - najbardziej dotykalnym, najłatwiej widocznym, najprościej wymiernym sprawdzianem własnej wartości narodowej. (...) Dla szerokich mas - to nie byle co. W bezinteresownej radości ze zwycięstwa barw własnego kraju, w bezprzyczynowym materiale smutku, kiedy triumfuje obcy, żywy jest - trudny do przebudzenia i utrzymania w aktywności w dniu pokoju - moment bezinteresownej solidarności narodowej. Sport ma to do siebie, że trafia do tych instynktów drogą nie rozumową, ale wzruszeniową, odszukuje je tam gdzie, zdawałoby się, wyżarło wszelką pierwotność wychowanie, obycie, nadmiar wrażeń. (...) Zainteresowanie sportem szerokich mas to nie tylko moda. To ujście dla tych uczuć solidarności zbiorowej, które są bardzo cenną wartością państwową. (...) W odruchu dumy, jaką czują dziesiątki tysięcy ludzi, gdy dowiedzą się, że ich barwy narodowe podniosły się na maszt olimpijski - jest nagłe i wartościowe zespolenie energii społecznej, proszkowanej przez codzienną konieczność wzajemnych wewnętrznych walk i tarć" (Matuszewski 1936).

\section{Architektoniczny wymiar widowiska sportowego}

Areną rozgrywania zawodów sportowych są stadiony i hale sportowe. Można je postrzegać z perspektywy ekonomiczno-społecznej i użytkowej (z uwagi na rozmach i ich wielkość są to budowle kosztowne, finansowane ze środków społecznych, a zatem w odpowiedzi na powszechną zgodę co do użyteczności), jak i architektonicznej i urbanizacyjnej - a więc w odniesieniu do ich walorów estetycznych, nawiązujących do wymiaru kulturowego.

Obiekty służące do organizacji imprez sportowych są obecnie obok architektury sakralnej najbardziej charakterystycznym elementem urbanistyki dużych i średnich miast. Niejednokrotnie są to budowle dominujące w architekturze miast, wręcz przytłaczające swoim ogromem (tak jest na przykład w stolicy Polski

17 Zamieszczonym także w numerze „Przeglądu Sportowego” z 1936 roku. 
Warszawie). Warto zauważyć, że stadiony piłkarskie jako przestrzeń mogą pomieścić tysiące i dziesiątki tysięcy ludzi z zachowaniem punktu centralnego, co ma swoje określone społeczne znaczenie.

Oryginalność architektury i walory estetyczne w powiązaniu z rozmiarami stadionów piłkarskich predestynują je do roli zasadniczych punktów orientacyjnych i elementów tożsamościowych wielu miast. Potwierdza tę tezę jedna z najsłynniejszych i najlepiej rozpoznawalnych budowli sportowych, jaką jest rzymskie Koloseum - najlepszy przykład roli tych obiektów w życiu miasta. Zbudowane w latach 70. I wieku n.e., stanowi wizerunek Rzymu jako metropolii od blisko dwóch tysięcy lat.

Podobnie rzecz się ma z najsłynniejszymi i największymi obiektami sportowymi zbudowanymi współcześnie, w XX i na początku XXI wieku, jakimi są stadiony piłkarskie. Ich powstanie i związane z nimi wydarzenia wplecione są w dzieje miast, współuczestnicząc w tworzeniu historii. Udostępniając możliwość obserwacji rywalizacji sportowej dla tysięcy widzów naraz, charakteryzują się ponadnaturalną w stosunku do reszty obiektów wielkością. To przesądza o ich wpływie na miejską architekturę, a ta z kolei jest w stanie wiele powiedzieć o życiu miasta.

Najsłynniejszy stadion mógł powstać tylko w kolebce światowego piłkarstwa - w Wielkiej Brytanii. Otwarty w 1923 roku w Londynie w dzielnicy Wembley przez króla Jerzego $\mathrm{V}$, mieścił ponad 80 tysięcy widzów. Jako najsłynniejsza arena piłkarska stadion Wembley zasłynął też jako największa sala koncertowa ${ }^{18}$. Po osiemdziesięciu latach stadion wyburzono i w jego miejscu zbudowano w latach 2003-2006 nowy o tej samej nazwie. Mieści dziewięćdziesiąt tysięcy widzów i jest obecnie jednym z najnowocześniejszych obiektów sportowych na świecie. W roku 2011 Wembley był gospodarzem Ligi Mistrzów, a w 2012 roku miejscem fantastycznej uroczystości otwarcia XXX Igrzysk Olimpijskich. Równie legendarnym, a jednocześnie najstarszym stadionem piłkarskim na świecie jest zbudowany w latach 1909-1910 Old Trafford w Manchesterze. W środowisku piłkarskim określany jako „Teatr marzeń”, uważany jest za najpiękniejszy klubowy (klubu Menchaster United) stadion w Wielkiej Brytanii.

Stadion o porównywalnie imponującej historii znajduje się w stolicy Niemiec Berlinie. Olympiastadion zawdzięcza swoją nazwę przeznaczaniu na igrzyska olimpijskie - w 1916 roku (VI w kolejności, które nie odbyły się z powodu wybuchu I wojny światowej) i słynne XI w 1936 roku $^{19}$. Z kolei największy w Niemczech

18 Dwa koncerty zespołu Queen, które odbyły się 11 i 12 lipca 1986 roku na Wembley, określa się dziś mianem najlepszych w historii tej grupy. Inny wielki zespół The Rolling Stones koncertuje tu w 1982 i 1990 roku. W 1992 roku ma miejsce szczególna impreza - The Freddie Mercury Tribute Concert, z której całkowity dochód został przeznaczony na walkę z AIDS, a w 1995 rekordowy (70 tys. widzów) koncert zespołu Bon Jovi. Michael Jackson wystąpił na stadionie Wembley piętnaście razy (w sumie ponad 1,1 miliona widzów), a druga wielka gwiazda muzyki pop, Madonna - dziewięciokrotnie.

19 Z uwagi na swoją bogatą historię (w tym bezpośredni udział Adolfa Hitlera w jego projektowaniu), marginalizowany w przestrzeni medialnej - funkcjonuje zgodnie ze swoim pierwotnym projektem jako obiekt lekkoatletyczny (XII Mistrzostwa Świata w Lekkoatletyce w 2009 r.) i jako stadion piłkarski (Mistrzostwa Świata w Piłce Nożnej w 1974 i 2006 r., a także na potrzeby zespołu Hertha BSC Berlin i stadion do gry w futbol amerykański klubu Berlin Thunder). 
stadion (83 tys. miejsc), Westfalenstadion ${ }^{20}$, zbudowany na potrzeby Mistrzostw Świata w Piłce Nożnej w 1974 roku w Dortmundzie, określany jest jako „opera niemieckiego futbolu”, co najlepiej ilustruje skojarzenie wielkich widowisk sportowych (meczy piłkarskich) z najwspanialszymi dziełami kultury.

Największa chyba obecnie potęga futbolowa, Hiszpania, ma Camp Nou w stolicy Katalonii Barcelonie i Santiago Bernabéu w stolicy kraju. Pierwszy to największy (ok. 100 tys. widzów) europejski stadion piłkarski, miejsce rozgrywania meczy najlepszej drużyny świata FC Barcelona; był areną zmagań piłkarskich mistrzostw Europy w 1964 roku, Mistrzostwa Świata w 1982 roku oraz Igrzysk Olimpijskich w 1992 roku. W dniu 17 listopada 1982 roku był miejscem zgromadzenia 129 tys. wiernych na mszy św. celebrowanej przez papieża Jana Pawła II. Estadio Santiago Bernabéu ${ }^{21}$ w Madrycie (dla ok. 90 tys. osób) wykorzystywany jest przez jedną z najlepszych drużyn świata Real Madryt.

Italia - kolejna mekka futbolu - ma słynny San Siro w Mediolanie i Stadio Olimpio w Rzymie, obydwa z wielką przeszłością i równie wielkie. Starszy San Siro (dla ok. 85 tys. widzów) powstał w 1926 roku na potrzeby piłki nożnej drużyny Milanu ${ }^{22}$, Stadio Olimpio to włoski stadion narodowy, na którym swoje mecze rozgrywają dwie rzymskie drużyny Lazio oraz Roma ${ }^{23}$.

Największy sportowy obiekt świata, słynna Maracana, znajduje się poza Europą - w Rio de Janeiro ${ }^{24}$. Zbudowany został na mistrzostwa świata w 1950 roku w Brazylii, a rekord widzów, blisko 200 tys. osób, został ustanowiony podczas historycznego meczu Brazylia-Urugwaj 16 lipca 1950 roku, przegranego przez gospodarzy 1:2.

\section{Widowisko sportowe w perspektywie mediów}

Bezsporny jest związek widowiska sportowego i mediów. W końcu to za ich pomocą zmagania sportowców przekazywane są tysiącom i milionom zainteresowanych (i niezainteresowanych), docierają wszędzie, do najbardziej odległych i, wydawałoby się, odizolowanych zakątków świata. To potężna siła, którą sport się żywi i dzięki której rośnie.

20 Obecna nazwa marketingowa Westfalenstadion to Signal Iduna Park.

21 Nazwa nie jest przypadkowa - powstał w 1947 roku za pieniądze pożyczone w banku przez prezesa klubu Realu Madryt, Santiago Bernabéu.

22 Nazwę zawdzięcza dzielnicy Mediolanu San Siro. W 1935 roku zostaje odkupiony przez miasto, a w 1947 udostępniony dla drugiej mediolańskiej drużyny Interu. Stadion San Siro nosi też nazwę Stadio Giuseppe Meazza na cześć słynnego gracza Interu Mediolan, a następnie piłkarza Milanu - Giuseppe Meazzy, mistrza świata z 1934 i 1938 roku.

23 Rozbudowany z myślą o XVII Letnich Igrzyskach Olimpijskich w 1960 roku w Rzymie i następnie w 1990 roku na Mistrzostwa Świata w Piłce Nożnej. Może pomieścić ponad 80 tysięcy widzów. Rozgrywane są na nim mecze mistrzowskie (m.in. finał piłkarskiej Ligi Mistrzów w 2009 r.), zawody lekkoatletyczne (Lekkoatletyczne Mistrzostwa Świata w 1987 r.), mitingi diamentowej ligi IAAF - Golden Gala, organizowane koncerty (np. amerykańskiej piosenkarki Madonny, irlandzkiego zespołu U2).

24 Swoją nazwę zawdzięcza lokalizacji na peryferiach Rio do Janeiro nad rzeczką Maracana. Oficjalna nazwa to: Estádio Jornalista Mário Filho w Rio de Janeiro w Brazylii. 
Wielkość i wszechobecność współczesnego sportu w istotnej mierze jest pochodną potęgi mediów. Nie deprecjonuje to w żadnym stopniu wewnętrznych wartości sportu, dzięki którym stał się on tym we współczesnym świecie, czym jest. A jest tym, bez czego współczesnego świata nie sposób sobie wyobrazić. Jednak nie można mieć wątpliwości, że fenomen $X X$ wieku, największy teatr $X X$ wieku, to wspólne dzieło samego sportu i pokazujących go (transmisje telewizyjne) mediów, których rozwój nastąpił także w tym stuleciu.

Sport w tym związku jest stroną ewidentnie korzystającą (podnoszone przez niektórych straty w postaci patologii sportu, za którymi stoi presja mediów, można w tym miejscu rozważań pominąć), jak również zależną. To media, ich zainteresowanie, przesądzają w znacznej mierze o sile, dynamice i kierunku rozwoju poszczególnych dziedzin sportu, o ich znaczeniu na tle pozostałych i w całej przestrzeni społecznej. Ostatecznie prestiż niektórych dyscyplin sportowych ma swój rodowód w słynnej puli nagród do rozdania wśród triumfatorów, co w prostej linii prowadzi do transmitujących zawody mediów. Przy czym opłaty wnoszone z tytułu praw do transmisji stanowią tylko część środków - reszta pochodzi ze sponsoringu wielkich firm reklamujących podczas widowiska sportowego swoje produkty. Nie trzeba dodawać, że reklama taka ma swój sens ekonomiczny tylko w warunkach wspomnianej transmisji.

W związku sportu i mediów sytuacja obydwu stron jest nieco odmienna. O ile sport, jego rozwój i funkcjonowanie, jest, jak to stwierdzono powyżej, w znacznym stopniu zdeterminowany wpływem mediów, o tyle same media nie mają takich uwarunkowań. We współczesnym świecie posiadają chyba najdalej idącą autonomię własnego działania i rozwoju. Nie zmienia to jednak faktu, że narodziny i rozwój sportu stanowią potężny impuls dla ich rozwoju i niezwykle atrakcyjną przestrzeń eksploatacji. Media żywią się widowiskami sportowymi w sensie dosłownym. Przekaz telewizyjny, radiowy czy poprzez rubrykę prasową stanowi stały dział (element i składową funkcjonowania) chyba wszystkich mediów. A są także jeszcze media (telewizje, programy, czasopisma) specjalistyczne. Fakt, że jest na nie popyt, najlepiej świadczy o znaczeniu sportu dla mediów - o wartości, jaką sport (widowisko sportowe) przedstawia dla świata mediów.

Wzajemne stymulujące oddziaływanie sportu i mediów stanowi interesującą, ale też stosunkowo dobrze uświadomioną płaszczyznę dyskusji o medialnej perspektywie sportu. Inną, nie mniej atrakcyjną tematyką jest kategoria „gwiazdy sportu". Wielcy sportowcy - czyli osiągający szczytowe wyniki w swoich dyscyplinach - stają się przedmiotem szczególnej sympatii ze strony szerokich kręgów społecznych. Zjawisko to jest znane od narodzin sportu. Zwycięzca zawodów sportowych staje się automatycznie i natychmiast bohaterem tłumów. Na marginesie - być może to jest podstawowy mechanizm przyciągający młodzież (chłopców) do sportu, ostatecznie w pewnym wieku każdy chłopak chce być bohaterem. Entuzjastyczna sympatia, afektywne zainteresowanie, uwielbienie, ubóstwieniu (bożyszcze kibiców), to uczucia, z którymi stykają się wielcy sportowcy od czasów antycznych olimpioników do dnia dzisiejszego ${ }^{25}$. Współczesne „gwiazdy sportu”

25 Wymowny jest przykład zwycięzcy biegu maratońskiego z I Igrzysk Olimpijskich Spirydiona Louisa, któremu grecki milioner i fundator stadionu olimpijskiego (przesądziło to o organizacji igrzysk w Atenach) Georgios Averoff zaproponował rękę swojej córki. 
swoją pozycję, wielkość i „blask” zawdzięczają w istotnej części mediom - ich uwadze skupionej na konkretnym wydarzeniu sportowym i jego bohaterach. Dzięki nim także przekłada się ona na całkiem wymierne, poza sławą, choć będące jej konsekwencją - korzyści finansowe. Przy czym częstokroć bajeczne zarobki, o jakich się słyszy, w swej zasadniczej części pochodzą z działalności pozasportowej, z tytułu udzielenia swojego wizerunku np. w reklamie. Trudno o bardziej widoczny przykład nierozerwalności świata sportu i świata mediów.

Widowisko sportowe jako największa arena dla największej widowni to miejsce „narodzin gwiazd”. Popularność największych sportowców, fascynacja i uwielbienie, którymi się cieszą wśród swoich kibiców, sprawiają, że stają się oni idolami dla szerokich rzesz młodzieży i nie tylko. U niektórych sportowców funkcjonowanie $w$ roli idola trafia $w$ ich predyspozycje osobowe, czyniąc z nich celebrytów. Zaczynając jako autorytet w swojej dyscyplinie, szybko pojawiają się w roli znawców w innych, często odległych dziedzinach życia. Przede wszystkim jednak stają się autorami trendów w modzie (fryzury znanych piłkarzy kopiowane przez szerokie rzesze naśladowców).

Widowiska sportowe w najbardziej prestiżowych dyscyplinach sportu, jak i szczególnie ważne (w fazie mistrzowskiej) rozgrywki, to także naturalne miejsce obecności osób znanych i sławnych ze świata kultury, sztuki i polityki - właśnie celebrytów. Zadeklarowane zainteresowanie jakąś dyscypliną sportu, co jest obecnie normą wśród osób z kręgu elity społecznej, kulturalnej (w tym także aspirujących do niej), zobowiązuje automatycznie do stałej obecności na meczach zespołu, któremu się kibicuje czy na turnieju mistrzowskim w ulubionej dyscyplinie. Charakterystyczne są tu mecze futbolu amerykańskiego i koszykówki w Stanach Zjednoczonych Ameryki, czy słynne turnieje tenisowe „Wielkiego Szlema” Australian Open, Roland Garros, Wimbledon, US Open.

\section{Podsumowanie}

Przeprowadzona analiza widowiska sportowego miała na celu możliwie wszechstronne ujęcie tego aspektu sportu. Próba wyodrębnienia poszczególnych wymiarów widowiska sportowego i nadania im swoistej tożsamości podyktowana była przeświadczeniem autora o ich rzeczywistym autonomicznym istnieniu i o potrzebie tak ukierunkowanej analizy - wartości takich analiz. Metodologicznie sprowadzała się do w miarę rzetelnego i przede wszystkim przekonującego ukazania możliwych perspektyw i podejść do widowiska sportowego jako integralnej, a zarazem szczególnej składowej sportu, w oparciu o wybiórczo (także zapewne, subiektywnie) dobrane i przedstawione dowody. Podejście takie - tak sformułowany cel i poczynione założenia co do zakresu oczekiwań - czynią tę procedurę otwartą na wszelkie możliwe dalsze analizy, koncepcje i ustalenia.

W wyniku podjętych działań i analiz osiągnięto stan pozwalający na wyszczególnienie - w przekonaniu autora wystarczająco udokumentowanych - obszarów i wymiarów widowiska sportowego, w których funkcjonuje ono w przestrzeni społecznej i kulturowej. Są to: 
1. Widowisko sportowe jako największy współczesny teatr.

2. Widowisko sportowe jako przedmiot i inspiracja dla sztuki.

3. Widowisko sportowe jako „fabryka” emocji.

4. Rekreacyjny wymiar widowiska sportowego.

5. Zdrowotny wymiar widowiska sportowego.

6. Ekonomiczny wymiar widowiska sportowego.

7. Społeczny i polityczny wymiar widowiska sportowego.

8. Architektoniczny wymiar widowiska sportowego.

9. Widowisko sportowe w perspektywie mediów.

Mając świadomość ograniczonych możliwości co do jednoznaczności, jak i konsekwencji przedstawienia wykazu możliwych perspektyw postrzegania i analiz widowiska sportowego, przyjęto rozwiązanie pozwalające na elastyczne dokonywanie korekt i uzupełnień, tak co do struktury, jak i odkrywanych treści. Wzajemna przenikalność ukazanych kategorii i wielorakie wzajemne powiązania stanowią zasadniczą przyczynę możliwych różnic zdań i odmiennych spojrzeń. Sytuacja taka jako naturalna skłania do prowadzenia dalszych interesujących analiz i obserwacji podjętego zagadnienia.

\section{Literatura}

Bittner I., Bryk A., O sporcie i kulturze fizycznej, poezji i medycynie czyli o etosie ciała ludzkiego, Wydawnictwo Uniwersytetu Łódzkiego, Łódź 2003.

Demel M., Skład A., Teoria wychowania fizycznego, Warszawa 1974 (wydania późniejsze 1986, 1995).

Grabowski H., Teoria wychowania fizycznego, AWF, Kraków 1987.

Grabowski H., Teoria fizycznej edukacji, PWN, Warszawa 1999.

Krawczyk Z., Polityczne i kulturowe walory EURO 2012.

Lipoński W., Humanistyczna Encyklopedia Sportu, Wyd. Sport i Turystyka, 1987.

Mała Encyklopedia Sportu, Wydawnictwo SiT, Warszawa 1984.

Mały słownik języka polskiego, red. S. Skorupka, H. Anderska, Z. Łempicka, PWN, Warszawa 1989.

Matusewicz Cz., Widowisko sportowe. Analiza psychospołeczna, AWF, Warszawa 1990.

Matuszewski I., Sport jako zespolenie energii społecznej i szkoła solidarności narodowej, „Przegląd Sportowy" 2 VI 1936.

Popularny słownik języka polskiego, red. B. Dunaj, Wydawnictwo Wilga, Warszawa 2003.

Rymarczyk R., Kultura masowa i kultura fizyczna, [w:] Z. Dziubiński, Z. Krawczyk (red.), Socjologia kultury fizycznej, AWF, Warszawa 2010.

Słownik języka polskiego PWN, Wydawnictwo Naukowe PWN, Warszawa 2000.

Słownik języka polskiego, red. J. Karłowicz, A. Kryński, W. Niedźwiedzki, wydanie fotooffsetowe, tom VI, Państwowy Instytut Wydawniczy, Warszawa 1952.

Słownik poprawnej polszczyzny, red. W. Doroszewski, PWN, Warszawa 1973.

Ustawa z dnia 18 stycznia 1996 roku o kulturze fizycznej, Dz.U. z 1996 r. Nr 25, poz. 113, art. 3 pkt 3. Ustawa z dnia 25 czerwca 2010 roku o sporcie, Dz.U. z 20N10 r. r 127, poz. 857, art. 2 ust. 1.

Ustawa z dnia 3 lipca 1984 roku o kulturze fizycznej, Dz.U. z 1984 r. Nr 34, poz. 181, art. 1 ust. 2 pkt. 3. Wielka Encyklopedia Powszechna PWN, Państwowe Wydawnictwo Naukowe, t. 10, Warszawa 1967. Wielka Encyklopedia PWN, Wydawnictwo Naukowe PWN, t. 25, Warszawa 2004. 